\title{
Compensatory Techniques for Modifying the Habitable Space of the Future: The Precedents of Application
}

\author{
Natalia Saprykina ${ }^{1, *}$ \\ ${ }^{1}$ The Moscow Architectural Institute (State Academy), Moscow, Russia \\ *Corresponding author. Email: nas@markhi.ru
}

\begin{abstract}
The article examines the problem of the use of compensatory techniques in the modification of the space of habitat, based on objective methods, which have developed, both in the natural sciences and in information's technology. Based on analysis of theoretical studies and design and experimental developments using compensatory techniques, the concepts and precedents of their application was been identified: Returning production objects to the city space; Reorientation and additional use of space; Transforming of the traditional relationships between landscape and architecture; Organizing a resource of the development of parallel spatial; Creating an alternative urban landscape; Conversion of areas affected by technological disasters; Compensation as reorientation of objects for new functions and habitat restoration; Cultivating a bygone land: a coastal city; Conversion of aircraft withdrawn by after their operation. The materials of the article and the results of the study can be a generator of new information, social and cultural innovation.
\end{abstract}

Keywords: Compensation techniques, Adaptation, Reorientation, Transformation, Conversion, Modification, Habitat space.

\section{INTRODUCTION}

During the formation of the living space in the conditions of the ever-increasing dynamism of life, ideas about the purpose of architecture and its place in the system of art and in society are constantly changing. In this regard, architects and researchers are trying to map out alternative ways of its formation, considering architecture as an integral part of a comfortable artificial habitat [1].

\subsection{The Relevance}

The solution to this problem necessitates a holistic approach to understanding the space of habitation as a system. It has a complex structure with universal laws of development, taking into account the principles of self-organization. Based

*Fund: This paper was funded by the Program of Fundamental Researches of the Ministry of Construction, Housing and Utilities of the Russian Federation and the Russian Academy of Architecture and Construction Sciences 2020, the Research Project 1.6.5. "Concept of project forecasting in the formation of the architectural space of the future" on alternative concepts in the organization of the surrounding space, such a system by the nature of formation is similar to a "living organism" adapting to the needs of society [2].

The emerging property of adaptability in the organization of the habitat space is on social and political changes based and is not only a technical or formal innovation. Management of adaptation for habitat change includes efforts to address interventions that aim to enhance effective approaches. For some of these management results, both in theory and in practice, future researches are proposed [3].

This has dictated by the need to implement activities related to the manifestation and use of adaptation principles that suggests the development of alternatives to improve people's living conditions (exploitation of environmentally balanced systems, reducing the impact of negative habitat, and developing a strategy for the economic use of nonreplaceable energy sources such as raw materials, products, etc.) [4]. 
The solution of the scientific problem in question is timely and relevant, as in architecture theory new principles of approach to the formation of habitat space as a system using compensatory techniques has revealed. In this case, it will be relevant to consider obtaining completely different properties of the system in the process of its creation, operation and further development.

\subsection{Problem Statement}

The purpose of the article is to identify concepts in a result of the analysis of precedents that apply compensatory methods of modification of the habitat space. The main tasks are:

- Determining the theoretical platform and prerequisites for the formation of a habitat space based on compensatory adaptation techniques.

- Identification of compensation techniques: precedents of application in theoretical research and design and experimental developments

The study of this problem is fundamental, as it has aimed at gaining new knowledge about the basic patterns of the formation of the habitat space. The results of the study can be a generator of new information, social and cultural innovation.

\section{THEORETICAL PLATFORM AND PREREQUISITES FOR FORMATION OF A HABITAT SPACE}

As part of the problem under study, based on objective methods developed in the natural sciences, it is important to pay attention to ways of adaptation in architecture, including the relationship between correction and compensation processes that complement each other in many functional processes.

Based on biomedical research, correction is a process of modification various altered functions of the system and implies a specific method of influencing it in order to correct abnormal defects. The correction process relates to external influence. In turn, compensation is a process of replacing missing or completely lost functions of the system and is a complex process aimed at restoring them. If the correction can change and adjust the system's capabilities to existing conditions, then compensation does not always give a full refund of lost functions. Both processes are interconnected and inseparable [5].

Compensatory processes in the natural sciences are an important type of adaptive reactions to system damage. Elements of such a system, not affected by the action of the damaging agent, take on the function of damaged structures by substitution or qualitative modification of it. This leads to certain structural changes in all parts of the compensating functional system [5].

The use of methods developed in information technology in the creation of a component and multi-layered object formation system is of interest in the comprehensive consideration of this problem. This requires the use of components with such qualities as reuse and replacement suitability, expandability, independence. This allows you to replace and update individual components of the system to organize them in order to provide certain functionality [6].

An equally important method of this study is the formation of common approaches to modeling adaptive organizational systems. This approach has based on the ability to present the organizational system as a family of models. The appropriate structural hierarchy has considered as a tool for adaptability, where uncertainty is one of the key features of adaptive management of the system [7].

It should be noted that the type of organization of the adaptive system model determines the choice of decomposition strategy (functional, stable and time subsystems), which determines the type of model received and its properties (composition, structure and behaviour process). To move to process management, you need to create a behaviour model, while the workflow model does not produce the desired result [8].

On basis of this the model there are appear new emergence principles of the formation of spatial habitat, where architectural objects are radically transformed and changed, having the opportunity to the self-organize. Receiving in this case the emergence features of architectural objects, as well as a model description of the properties of the system will allow on this basis to come to their synthesis and to develop a holistic model of the system in the context of the social dynamics of the development of society.

In classifying systems, the emergence can be the basis of their systematics as their criterion. In this case, the system is definably by the environment and creates its own environment, 
which in turn affects the system and constructs it [9]. The new approach to the use of the principles of emergence allows us to reveal the method of modelling the environment of life in a changing reality.

\section{TOOLS FOR THE FORMATION OF COMPENSATORY TECHNIQUES: PRECEDENTS OF APPLICATION}

The use of compensatory techniques of adaptation of architectural objects allows revealing the concepts of modification of the space of habitat and precedents of their application. Analysis of theoretical research and design and experimental developments using compensatory techniques to modify the habitat space revealed the following concepts for solving this problem.

\subsection{Returning Production Objects to the City Space}

Due to the use of innovative non-polluting technologies, many the production objects to the

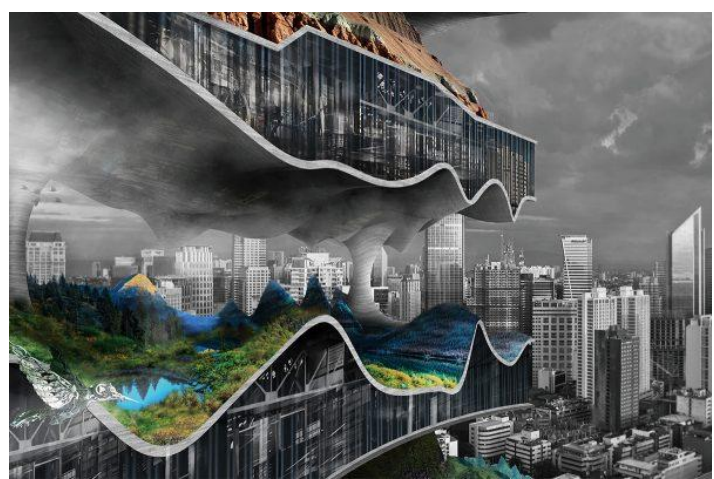

Figure 1 The project "Vertical Factories in Megacities" (USA) 2017.

\subsection{The Reorientation and Additional Use of Space}

The space of the city is a natural habitat of man, created by humans, and so is why this environment transforms humans [11]. The increasing pressure on areas with high capacity prevents people from living in a place that is within reach for living in here.

Compensation of this situation can serve by the design concept "Manhattan Ridge" (authors Zhenjia Wang, Xiayi Li) as affordable housing for people who work in Manhattan represents a new type of space for living. The authors' proposal simulates the
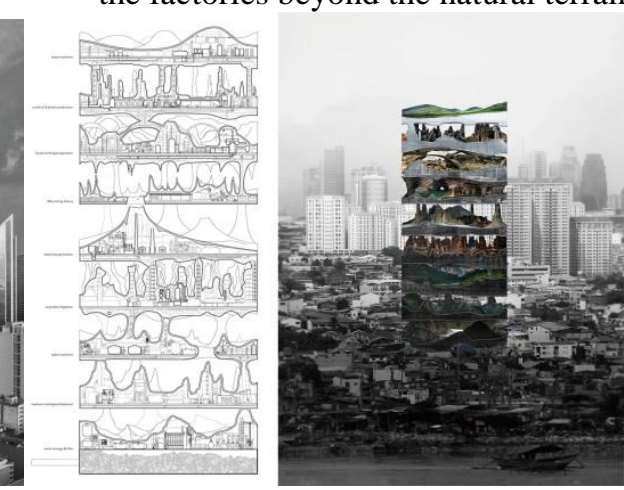

urban environment can return. The compensatory technique is to bring such factories back to the city, allowing them to achieve zero carbon emissions, be energy efficient and provide a better quality of life for residents. City plants will be closer to residents, skilled workers, suppliers, technical and research centers [10].

This approach is embodied in the project concept "Vertical Factories in Megacities" for cities of the future (authors of Tianshu Liu, Linshen Xie), where factories that were formerly the small objects will be combined together in high-rise vertical plants in megacities ("Figure 1"). This will solve the following environmental problems:

- the sustainable management of waste with no disposal sites and appropriate waste collection vehicles to reduce the efficiency of recycling, the proposed concept will address these problems.

- the return of nature to the city - after recycling the waste they will be transformed for use in the creation of different types of natural environment and turned into a new urban landscape, hiding the factories beyond the natural terrain. process of reforming and redefining of this territory as an open space for people by creating a dynamic vertical space where movement to and from work should be simple and convenient [12].

The proposed vertical system provides in addition to the two lower levels, for the organization of production and housing, the creation of a top level, designed for agricultural activities and recreational activities. Ideally, in this proposed new giant model of social life, people will be able to work "next" to place of living, consume and recreate "below," and live separately from their workplace "upstairs." 


\subsection{The Transforming of the Traditional Relationships Between Landscape and Architecture}

An example of this compensatory concept is the "New York Horizon" proposal (authors Ethan Sun, Jianshi Wu). Instead of building another tower in the city, the project envisages a new concept of lowering the central park grounds into the ground. This approach are related to the concept of "gap" in the theory of the formation of the habitation space, where in the context of conceptual architectural searches the void is structured and becomes a source of "self-organization" of the form and content of the object [13].
The project has designed to contrast with the densely constructed buildings and tall skyscrapers of the city. This will create a new urban organization where the newly built landscape will become a unifying part of the city [14]. Glass facades of skyscrapers will reflect the natural landscape of the park and create the illusion of an infinite natural world ("Figure 2"). The aim of the concept is to bring back the traditional relationship between landscape and architecture. Instead of building long, flat landscapes surrounding and complementing individual architectural buildings, the natural landscape in this sentence is the central element.

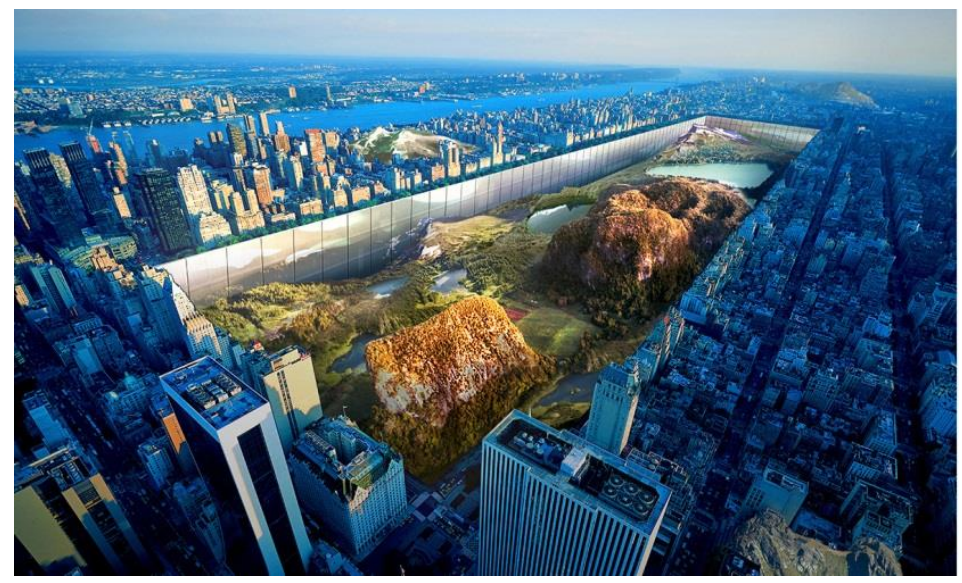

Figure 2 The project "New York Horizon" (USA) 2016.

\subsection{Organizing a Resource of the Development of Parallel Spatial}

This idea of the concept will intended to implement in the Manhattan - the most populous area of New York. Here, for the whole city, the density of high-rise buildings can not only cause inconvenience to people's lives, but also makes people feel depressed, which does not contribute to their physical and mental health [15].

To compensate for and solve such problems as the narrow and cramped space of the city, traffic jams, etc., in the concept of "Parallel Manhattan" (authors Jiyun Dong, Jiangchen Mou, Xiping Han, Xin Liuyu) the urban environment is modernized, dividing the urban space into two independent parallel levels. Formed parallel Manhattan has designed to meet different needs and has provided users with a variety of options [16].

Taking into account the lighting of the lower space, the authors choose glass as the main building material because of its reflective and transparent properties. Parallel space, according to the authors, is important for creating a new urban space and will be able to compensate for the solution of existing problems.

\subsection{Creating an Alternative Urban Landscape}

The analysis of the city and further study of cultural, social and economic issues reveals the most common and pressing problems of concern to the population. One promising study has shown that a huge increase in the number of residents will require the creation of vertical development of the habitat space, where the "porosity" of the territory can claim as an alternative concept in terms of claustrophobia [17]. This is due to the current situation of endless city walls, the lack of green spaces and the presence of polluted air, the excessive use of electricity to maintain the level of light, the presence of crowded pedestrian alleys and str eets. 
The idea of the concept "New City Grid Floating above Existing Cities" (authors Sergej Pogorelov, Siarhei Kuratski, Andrei Heldenko, Anastasiya Neumiarzhytskaya and Dimitri Kiselev) is to create an urban grid over cities as an independent space consisting of many neighborhoods. The structure provides space for buildings, green spaces and its own transport infrastructure. The system provides a balance between the created environment and the polluted lower city, thanks to its self-regulating and intelligent technologies [18].
The aim of the alternative landscape is to provide people with a sustainable city with diverse and complex environments, where recreational and social activities have mixed with transit zones ("Figure 3"). The environmental qualities of the alternative city has enhanced by new technologies and software elements, which leads to the solution of several urban problems. Communication between zones and local buildings carried out on hanging transport routes [18].

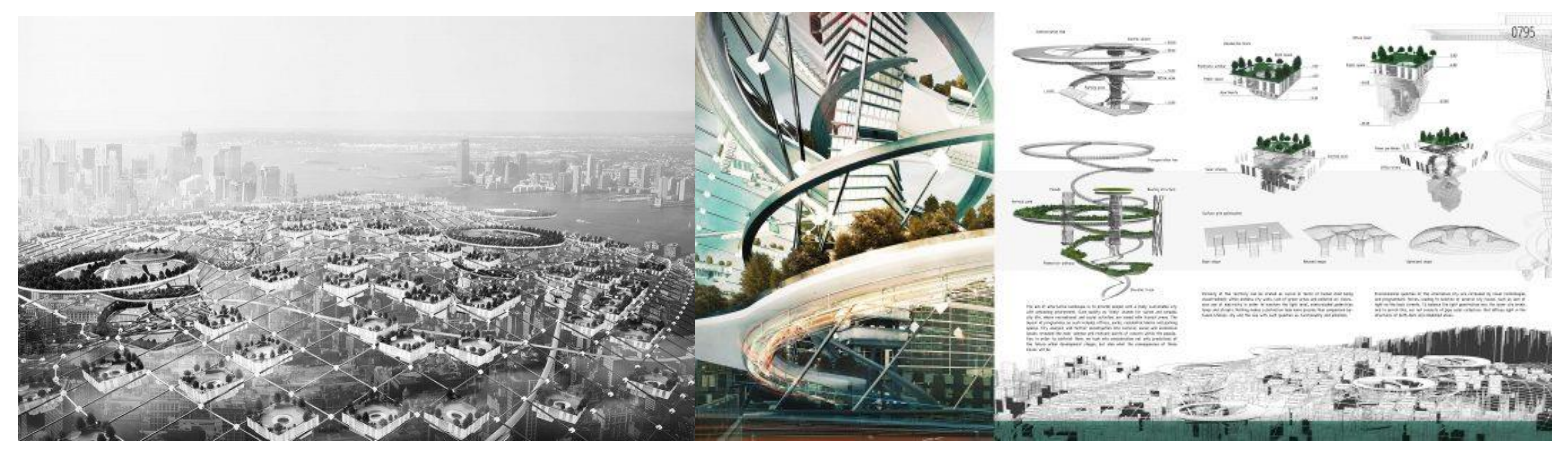

Figure 3 The project «New City Grid Floating Above Existing Cities» (Belarus) 2016.

\subsection{The Conversion of Areas Affected by Technological Disasters}

Recently, around the world there is a situation associated with the presence of objects that have a huge number of items abandoned and sent to landfills [19]. The challenge of regenerating "abandoned architecture" in concept "The Displacement or the Revolt of Abandoned Architecture" (by Ko Anthony, Chun Ming) is to restore such objects. In this regard, the Government in Japan has created artificial islands in the Gulf of Tokyo as a way to bury the evidence of earthquakes, as well as indirectly reduce landfills. This is where, with the help of boats and ships, such facilities moved and then recycled in local factories, providing builders with new design systems ("Figure 4"). The spatial structure located on the island will constantly filled with new objects in stages, and eventually it will reach saturation [20].

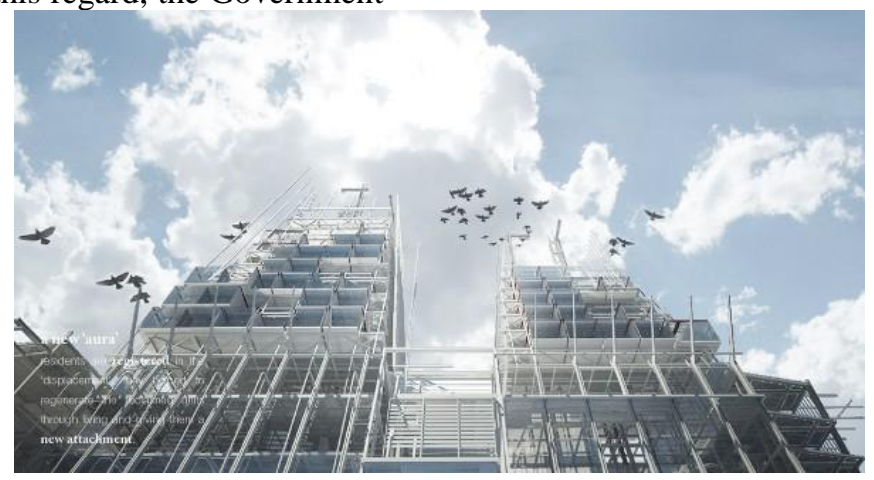

Figure 4 The project «The Displacement or the Revolt of Abandoned Architecture» (Hong Kong) 2016.

In this case, the "hidden" reconstruction method involves the use of techniques to work with the historical environment, while the "incorporation" method to base on including new buildings into the existing context. The contextual method, as a way of interconnecting a new object with the environment or individual buildings within the complex, is a kind of environmental adaptation that takes its start in achieving the integrity of the building [21]. 
This compensatory concept can also traced to the project "Rehabilitation of Chernobyl's zone", which proposes to create a tourist infrastructure with many facilities of different purposes, a transport network and a scientific base (Group of ZA Architects, 2012). The objectives of the project are to socialize the area closed to the public, both for tourism and scientific activities in order to restore the ecological balance and even attract investment [22]. According to the authors of the concept, it is possible to develop different types of tourism, for example, such as extreme, industrial, gaming, and in addition - ecological and photo safari.

\subsection{The Compensation as Reorientation of Objects for New Functions and Habitat Restoration}

The abrupt use of marine installations and the operation of marine vessels pose a high potential risk of oil spills, which for decades has threatened the entire marine ecosystem. There is a need to create such facilities to respond instantly to an oil spill, to restore a damaged ecosystem and to offer all creatures shelter from future disasters [23]. The "Noah Oasis: Rig to Vertical Bio-Habitat" proposal (authors of Ma Yidong, Zhu Zhonghui, Jiang zhe), created on the basis of a drilling rig, is a structure that transforms disposed of drilling facilities into a vertical biological habitat ("Figure 5").

The original installation will be a reactor center, where the spilled oil will transformed into a catalyst for the creation of building materials, as well as a recreation and research center. Ultimately, when sea levels rise to catastrophic, such a structure will continue to remain above sea level. In this way, this facility will become a vertical habitat for the rehabilitation of nature and help revive biodiversity [24].

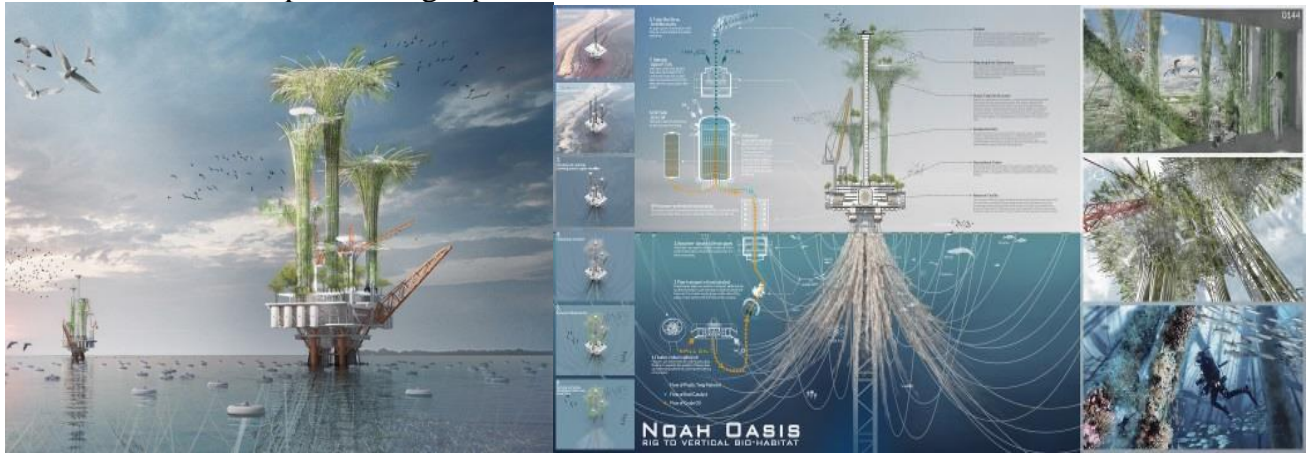

Figure 5 The project «Noah Oasis: Rig to Vertical Bio-Habitat» based on drilling rig (China) 2015.

\subsection{Cultivating a Bygone Land: a Coastal City}

Because of global climate change, many countries and regions suffer from the challenges of rising sea levels and the situation where the territory will disappear in the coming years. In the project of city for the cultivation of the bygone land "Floating City" (authors of Zijie Nie, Chen Shen, Jian Zheng) are proposes to build a number of skyscrapers in coastal waters and to deal with the problems caused by sea level rise.

The organization of architectural arrays are used for slow the speed of ocean currents flowing around buildings. At the same time, sand and soil in the water are able to settle in the form of sediments and gradually create new islands over time. Thanks to the skyscraper's design, the area of land flooded with seawater is being converted into an artificial landscape to provide people with a place to live and operate, protecting them from natural disasters such as hurricane and flooding [25].

When you create a vertical ecosystem that provides greening of homes for humans, it can also become a seed repository for the preservation of plant diversity in different regions. In addition, the large number of artificial components located between underwater structures can serve as a place to protect and restore coral reefs. The proposed concept of growing land with buildings is an alternative to traditional architectural design: first land is creating and then architectural objects are creating [26].

\subsection{The Conversion of Aircraft Withdrawn by After Their Operation}

Due to the major aviation crisis, Boeing's aircraft manufacturer, thousands of 737 Max facilities cannot fly and are stored at airports. 
Meanwhile, there is a large shortage of housing, and many social groups are unable to find a place to live because they have nowhere to live. Parts of this group of peoples are military veterans. To them has denied usually in the opportunity to start a new life as civilians because of the high cost of living and inadequate housing [27].

The idea behind the concept of "The Boeing 737 Max Tower" (author Victor Hugo Azevedo, Cheryl

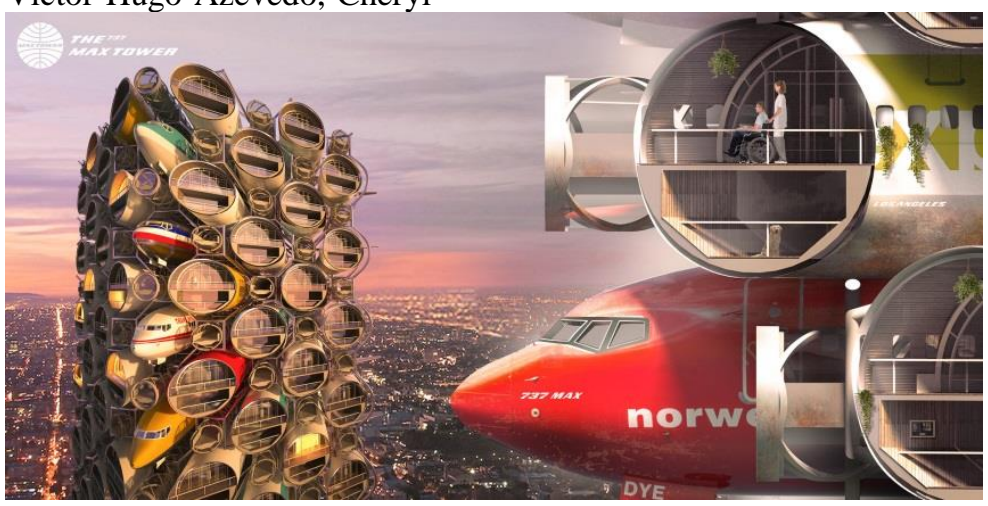

Figure 6 The project «The Boeing 737 Max Tower» (USA) 2020.

\section{PRACTICAL SIGNIFICANCE}

The practical significance of the study results is that for the first time a focused, comprehensive study carried out to identify new areas of development in architecture. This allows to developing the basics of the formation of habitat of a new generation, using modern progressive compensation techniques. The results of the study could become "a roadmap" for the carrying on to life the events of use of adaptation principles that will allow alternative approaches to improve people's living conditions.

\section{CONCLUSION}

Because of the author's consideration of the emerging directions in scientific research and design and experimental developments using compensatory methods for modifying the living space, the following new approaches and innovative concepts have identified in the formation of the architectural space of the future in the following directions:

- The returning production objects to the city space are associated with the use of innovative technologies, when many plants can return to the city. This allows for zero carbon emissions and a better quality of life for residents, allowing employees to go to work rather than moving around by car.
$\mathrm{Lu} \mathrm{Xu}$ ) is to use the plane's spatial potential and giving them a second life as part of a skyscraper. This allows not only provide comfortable and pleased living conditions for veterans, but also their physical and mental well-being, as well as social needs ("Figure 6"). The authors believe that this project is not just a cult tower, but also a reproducible construction system that can be used in many different contexts [28] 
model of the city. The system compensates for the environment contaminated by the lower city thanks to its self-regulating and intelligent technologies.

- The conversion of areas affected by technological disasters are related to the problem of replacing "abandoned architecture" by creating artificial islands as a way to bury evidence of earthquakes, as well as indirectly reducing landfills. The spent parts of the buildings moved to the island are being recycled in a local factory, providing builders with new constructive systems from which restored facilities will built.

- The compensation as reorientation of objects for new functions and habitat restoration is relevant when solving an environmental problem to respond instantly to an oil spill. The proposed solution is a structure that transforms recycled drilling facilities into vertical biological habitats to restore a damaged ecosystem and offer all creatures refuge from future disasters.

- The cultivating a bygone land as a coastal city is associated with the problem of sea level rise and the situation when the territory may disappear in the next years. The erection of massive skyscrapers in coastal waters allows slowing down the speed of ocean currents and gradually creating the new islands with artificial landscape. This will provide people with a place to live, protecting them from natural disasters such as hurricane and flooding.

- $\quad$ The conversion of aircraft decommissioned by the manufacturer Boeing is to use the spatial potential of the aircraft and give them a second life in the form of a skyscraper. This allows not only providing a comfortable living environment for military veterans, but also offers a variety of services that ensure the physical and mental well-being of veterans as well as their social needs.

The research carried out by the author made it possible to single out innovative concepts of using compensatory techniques for modifying living space in the theory of architecture and to give a direction to the search for their basic laws. This makes it possible to define fundamentally new modern scientific paradigms and methods used for the long-term development of the spatial habitat of the future.

\section{AUTHORS' CONTRIBUTIONS}

This paper is independently completed by Natalia Saprykina.

\section{REFERENCES}

[1] N.A. Saprykina, I.A. Saprykin, Sustainable development of spatial habitat Environment as a challenge to civilization in: IOP Conference Series: Materials Science and Engineering (MSE). 2018, Vol. 463, pp. 1-6. doi: $10.1088 / 1757-899 \mathrm{X} / 463 / 2 / 022052$

[2] D. Tomozeiu, S. Joss, Adapting adaptation: the English eco-town initiative as governance process // Ecology and Society 2014, № 19 (2), p. 20. URL: http://dx.doi.org/10.5751/ES06411-190220

[3] The governance of adaptation: choices, reasons, and effects. Introduction to the Special Feature in: ECOLOGY AND SOCIETY, September 2016, 21(3):37 (210337). doi: 10.5751/ES-08797-210337

[4] N.A. Saprykina, Innovative Tricks of Adaptations the Architectural Objects as Alternative Ecosystem // International and technology conference "FarEastCon-2019" IOP Conf. Series: Materials Science and Engineering, $753 \quad$ (2020) $032003 \quad$ IOP Publishing. URL:doi:10.1088/1757899X/753/3/03200

[5] Fundamental aspects of compensatory and adaptive processes (Fundamental'nye aspekty kompensatorno-prisposobitel'nyh processov) in: Materials of the Ninth All-Russian Scientific and Practical Conference September 22-24, 2020, Novosibirsk / Under Ed. M.I. Vojvoda. Ministry of Science and Higher Education of the Russian Federation, FIC FTM. Novosibirsk: SO RAS, 2020, 160 p. doi: 10.15372/FUNDAMENTAL2020VMI. [in Russian]

[6] V.V. Kulyamin, Component architecture of the environment for testing based on models (Komponentnaya arhitektura sredy dlya testirovaniya na osnove modelej) in: SOFTWARE, 2010, № 5, pp. 54-75. URL: https://www.ispras.ru/publications/komponent naya_arkhitektura_sredy_dlya_testirovaniya_n a_osnove_modeley.pdf [in Russian] 
[7] B.V. Chernikov, S.N. Antonchikov, Modeling of adaptive organization in: Proceedings of 2017 10th International Conference Management of Large-Scale System Development (MLSD 2017). Danver: IEEE, 2017. p. 1-4. doi: 10.1109/MLSD.2017.8109605

[8] G.N. Kalyanov, B.V.Kuprianov, I.G. Fiodorov, The role of decomposition in organizational system modeling in: CEUR Workshop Proceedings, Volume 2064, 2017, pp. 380-387, 2nd International Scientific Conference "Convergent Cognitive Information Technologies"

[9] E. N. Knyazeva, Innovative Complexity: methodology of organizing complex adaptive and network structures (Innovacionnaya slozhnost': metodologiya organizacii slozhnyh adaptivnyh i setevyh struktur) in: Philosophy of science and technology, 2015, Vol. 20, № 2, pp. 50-69. [in Russian]

[10] T. Liu, L. Xie, Vertical Factories in Megacities (USA) 2017. URL: http://www.evolo.us/vertical-factories-inmegacities/\#more-35759

[11] I. Kukina, The Architecture of the Conflicts // Proceedings of the 2nd International Conference on Architecture: Heritage, Traditions and Innovations (AHTI 2020) / Series: Advances in Social Science, Education and Humanities Research. doi: https://doi.org/10.2991/assehr.k.200923.066

[12] Z. Wang, X. Li, Manhattan Ridge: Affordable Housing for Commuters (USA) 2018. URL: http://www.evolo.us/manhattan-ridgeaffordable-housing-for-commuters/\#more36183

[13] M.V. Dutsev, Concept gap in modern architecture (Koncepciya promezhutka V sovremennoj arhitekture) in: Volga Scientific Journal / Nizhnygor. State architecture.-builds. Un-t. N. Novgorod, 2010. № 1. pp. 122-127. URL: https://archinauka2222.livejournal.com/1389.html [in Russian]

[14] E. Sun, J. Wu, New York Horizon (USA) 2016. URL: http://www.evolo.us/new-yorkhorizon/\#more-34989

[15] N. Kasyanov, Research on the Similarities of Morphogenesis in: Architecture and Nature in:
Proceedings of the 2nd International Conference on Architecture: Heritage, Traditions and Innovations (AHTI 2020) / Series: Advances in Social Science, Education and Humanities Research. doi: https://doi.org/10.2991/assehr.k.200923.045

[16] J. Dong, J. Mou, X. Han, X. Liu, Parallel Manhattan (China) 2017. URL: http://www.evolo.us/parallelmanhattan/\#more-35794

[17] I. Krasheninninkov, Research Directions to Study Urban Tissue «Porosity» in: Architecture and Modern Information Technologies, 2017, 3(40), pp. 215-226. URL: http://marhi.ru/eng/AMIT/2017/3kvart17/16_k rasheninninkov/index.php

[18] S. Pogorelov, S. Kuratsk., A. Mikhalenko, A. Neumiarzhytskaya, D. Kiselev, New City Grid Floating Above Existing Cities (Belarus) 2016. URL: http://www.evolo.us/new-citygrid-floating-above-existing-cities/\#more35407

[19] V.N. Logvinov, From "green building" to nature-integrated architecture. The principle of regeneration (Ot «zelenogo stroitel'stva» k prirodo-integrirovannoj arhitekture. Princip regeneraciii), Part 1. (18.10.2016). URL: https://ardexpert.ru/article/7604 [in Russian]

[20] K. Anthony, C. Ming, The Displacement Or The Revolt Of Abandoned Architecture (Hong Kong S.A.R). URL: http://www.evolo.us/thedisplacement-or-the-revolt-of-abandonedarchitecture/\#more-35010

[21] A.V. Tatarchenko, Medium's approach in architecture: from theory to implementation (Sredovoj podhod $\mathrm{v}$ arhitekture: ot teorii $\mathrm{k}$ realizacii) in: Modern knowledge-intensive technologies. - 2018. - № 9. pp. 115-119. URL: http://toptechnologies.ru/ru/article/view $? \mathrm{id}=37170 \quad$ [in Russian]

[22] Tourist infrastructure in the Chernobyl zone (Group of AA Architects) 2012. URL: http://wiki.ru/sites/arkhitektura_i_stroitelstvo/i d-news-397811.html

[23] S.A. Kizilova, Form and functional features of modular floating structures in: E3S Web of Conferences. - 2019. - Vol. 91. - P. 05013 (17). doi: 10.1051/e3sconf/20199105013 
[24] M. Yidong, Z. Zhonghui, Q. Zhengyu, J. Zhe, Noah Oasis Skyscraper transforms offshore oil rigs into vertical bio-habitats (China) 2015. URL: $\quad$ https://inhabitat.com/noah-oasisskyscraper-transforms-offshore-oil-rigs-intovertical-bio-habitats/noah-oasis-oil-rigskyscraper-evolo-2015-4/

[25] Z. Nie, C. Shen, J. Zheng, Floating City: Cultivating The Gone Land (USA) 2020. URL: http://www.evolo.us/floating-citycultivating-the-gone-land/

[26] N. Saprykina, Innovative Tricks of Adaptations the Architectural Objects as Alternative. Ecosystem IOP Conf. Ser.: Mater. Sci. Eng. 753, $032003 \quad$ (2020). doi:10.1088/1757-899X/753/3/032003

[27] L. Ayala, The dynamics of housing deprivation [Text] / L. Ayala, C. Navarro in: Journal of Housing Economics, 2007, № 16, pp. 72-97.

[28] V.H. Azevedo, C.L. Xu, The Boeing 737 Max Tower (USA) 2020. URL: http://www.evolo.us/the-boeing-737-maxtower/\#more-36665 